\title{
The Recording Industry as the Enemy? A Case Study of Early West German Metal Music
}

\author{
Jan-Peter Herbst ${ }^{1,2}$ iD
}

Received: 29 June 2021 / Accepted: 16 September 2021 / Published online: 22 September 2021

(c) The Author(s) 2021

\begin{abstract}
Rock and metal music have a complex relationship with the entertainment industries. They rely on commodified products but are also cautious towards the capitalist system with its instrumentalist mechanisms. This article examines early metal music from West Germany in the 1980s with its rock precursors in the 1970s to shed light on the music industry's positive side other than the commonly portrayed enemy or villain image. Using journalistic sources, including magazines, biographies, documentaries, besides the music release database Discogs, the research reconstructs the independent recording industry for metal, examining key record companies, distribution channels and production staff, as well as their principles and intentions. The findings suggest that in the formative phase of German metal, the boundaries were blurred between fans, artists and entrepreneurs, most acting out of a passion for music. Fan practices, such as music-making, journalistic writing or tape trading, became serious leisure careers, eventually enabling some of the bands, journalists and entrepreneurs to make a living from their metal-related activities; others remained "semi-professional". Communal spirit characterised German metal, and most of "the industry" worked together with the scene. The joint efforts made it possible for Germany to develop from a weak production location for subcultural rock music compared to the dominant cultures of the USA and UK to one of the leading recording industries for metal music. Rather than "the enemy" with manipulative intentions, the independent metal industry was a cultural intermediary and enabler of subcultural production and consumption.
\end{abstract}

Keywords Metal music $\cdot$ Krautrock $\cdot$ Recording industry $\cdot$ Serious leisure $\cdot$ Germany

Jan-Peter Herbst

j.herbst@hud.ac.uk

1 Department of History, English, Linguistics and Music, University of Huddersfield, Huddersfield, UK

2 School of Arts \& Humanities, Department of History, English, Linguistics and Music, University of Huddersfield, Queensgate, Huddersfield HD1 3DH, UK 


\section{Introduction}

Music subcultures have a complex, sometimes difficult relationship with the entertainment industries. On the one hand, every subculture relies on the entertainment industries to provide commodified products such as music releases, merchandise and other fan memorabilia, without which no subculture can exist (Spracklen 2019). On the other hand, countercultures distinguish themselves from the mainstream for reasons like authenticity, perceived superiority or artistic quality (Kahn-Harris 2007). Although this dilemma tends to be more pronounced in subcultures with anti-commercial ideologies like rock and metal, it is not limited to them (Spracklen 2013) or music at all. All leisure is part of a liberal capitalist industry that provides for consumer needs (Bacon 1997).

'Culture-as-leisure' describes a claim by Spracklen $(2009,2011)$ that popular culture is characterised by activities and spaces constructed and contested through leisure. Even though supposed to be freely chosen and positive for the individual, leisure activities are influenced by social, economic and political conditions (Parker 1971). Following Spracklen's (2009, 2011, 2019) argument, culture-as-leisure is inextricably linked to and produced by Adorno's (1991) culture industry. Spracklen's $(2009,2011,2013)$ dichotomous definitional framework of leisure defines 'instrumental leisure' as the product of hegemonic capitalism and nation-states intended to facilitate consumption. It is the opposite of 'communicative leisure', which is freely chosen and less influenced by capitalist, hegemonic forces. Music as a form of leisure has the potential to provide a 'communicative' space or lifeworld (Habermas 1984), but its potential is limited by the power of capital (Spracklen 2019).

Metal music is an interesting leisure space because it opposes the mainstream (Hjelm et al. 2011). Attending or playing metal concerts and writing about music, or engaging with it in other ways, are leisure activities that allow fans or artists to exercise communicative leisure. In so doing, individuals gain agency to resist instrumental influences from mainstream society (Spracklen 2014, 2020, pp. 48-50).

Spracklen recently described the complex relationship between metal and the culture industry as follows:

it cannot be denied that all forms of music today-even folk and classical, and marginal forms of pop-are mediated and constrained by the culture industry in one way or the other. That is, all are the product of artists who want their music to be heard and appreciated by listeners, and all artists and listeners have their taste and values shaped by what they learn from their own interactions with culture industry. Thus, heavy metal is mediated by the culture industry in a different way to the classical music, but they are both mediated and constrained to some degree by norms and expectations. (Spracklen 2019, p. 269)

This article takes Spracklen's observation as a starting point to examine the relationship between metal as leisure space and profession and the culture/ 
recording industry. It seeks to challenge the prevailing view that portrays the industry as "the enemy" (Krumm 2012, p. 204) because of its conspicuous links to commerce (Messick 2020; Spracklen 2019), which contradicts metal's appreciation of the authentic, subversive and transgressive (Kahn-Harris 2007). Even though the metal recording industry may indeed be concerned with economic profitability to stay in business, I intend to show that, in general, it is not instrumentalist. Rather, it is community-oriented and provides the communicative leisure space for metal fans and even artists and those engaged in the record industry. With most acting out of a passion for music in this genre, the distinction between fan, artist and entrepreneur can be blurred.

This research is a case study of metal music produced in the Federal Republic of Germany in the 1980s to early 1990s. Metal emerged in the UK and USA by the early 1970s before spreading to Western Europe, Australia and Japan in the 1980s and ultimately reaching countries worldwide (Wallach et al. 2011). According to Weinstein (2011, p. 44), the 'first phase of metal's diffusion was from more economically and technologically developed area to less developed ones'. When rock music arrived in Germany in the 1950s, the infrastructure for rock production was indeed inferior, but the krautrock boom in the early 1970s established an infrastructure for subcultural music from which West German metal benefitted in the 1980s. Krautrock's emphasis on left-wing counterculture and independent production structures for niche rock music influenced German metal musicians and industry entrepreneurs alike, which led to mutual and supportive cooperation. It meant that on the one hand, leisure space was less likely characterised by instrumental exploitation, but on the other that both artists and entrepreneurs tended to be less "professional", and often, not even the most successful could make a living from metal. For most artists and entrepreneurs in the 1980s and 1990s, metal was more of a serious leisure career, the 'systematic pursuit of an amateur, hobbyist, or volunteer activity sufficiently substantial, interesting, and fulfilling for the participant' (Stebbins 2009, p. 14).

After discussing the role of record labels, this study outlines West Germany's post-war popular music industry and the emergence of krautrock to demonstrate its momentum for the country, preparing the production of countercultural rock music, which was crucial for the metal boom in the 1980s. Most of the literature suggests that metal emerged from nowhere in Germany, with the young scene "pulling together" and creating a network of bands, fan clubs, underground zines and national magazines, record labels and studios from scratch (Elflein 2017; Klüsener 1989; Krumm 2011). While that is true given the rapidly developing metal scene in the 1980s, the foundation was laid through previous achievements of subcultural rock music in the form of krautrock.

The research then empirically explores the beginning of West German metal structurally, looking closely at record companies, recording studios and individuals that supported the young scene. Methodically, the investigation is based on two forms of data. First, literature on German record labels (Gehlke 2017; Krumm 2012), collected German metal magazine articles and other journalistic accounts 
(e.g., Mader et al. 1998; Schmenk \& Krumm 2010) are analysed for a qualitative understanding of the scene. Second, an analysis of quantitative data from the music database Discogs sheds light on the infrastructure of early German metal to gain a more comprehensive picture of the industry. ${ }^{1}$ The mixed-methods approach may be understood as a form of qualitative document analysis (Altheide \& Schneider 2013; Bowen 2009), which aims to 'understand culture, social discourse, and social change [...] by studying documents as representations of social meanings and institutional relations' (Altheide \& Schneider 2013, p. 5). It follows general principles of qualitative research in the social sciences, especially inductive and thematically structured coding (Corbin \& Strauss 2008; Glaser \& Strauss 1976) and theoretical sampling (Altheide \& Schneider 2013, p. 56). Understanding documents as 'any symbolic representation that can be recorded or retrieved for analysis' (Altheide \& Schneider 2013 , p. 5), qualitative document analysis is open to various forms of data, including books, magazines, event programmes, newspapers, charts, survey data, institutional and public reports (Bowen 2009, pp. 27-28), which allow for in-depth analysis of individual or comparative case studies through an iterative process of analysing, comparing and interpreting data sources and emerging themes. Qualitative document analysis gains in usefulness and rigour when combined with another method to corroborate the findings; a quantitative component thus mitigates some of the weaknesses of qualitative approaches through a larger sample size. This article analyses various sources and data forms, as listed before, to understand the early West German metal music industry by examining its structures, working practices and perceptions and by comparing them with industries in the USA and UK.

The study concludes with an evaluation of the early metal industry, suggesting that it was run in a communal spirit by dedicated serious amateurs, some of whom eventually became professional, through extended fan practices and serious leisure. Rather than "the enemy" (Krumm 2012, p. 204) with instrumental intentions and manipulative practices (Adorno 1991; Golding \& Murdock 1996; Spracklen 2009, 2011, 2013), the independent metal industry was a 'cultural intermediary' (Bourdieu 1986; Negus 1999, 2001, 2010) and enabler of subcultural production and consumption.

\section{Literature Review: Record Labels, a Necessary Evil?}

In popular music research, the business of record production has long been viewed with suspicion, influenced by the long shadow of the Frankfurt School (Adorno \& Horkheimer 1979; Benjamin 1969). Particularly influential were Adorno's (1976, 1991) writings on the culture industries (see Negus 2010, pp. 37-39), in which he

\footnotetext{
1 The literature on German metal is small but growing. Zaddach (2018) and Okunew (2021) present a detailed analysis of metal in the German Democratic Republic, which differed significantly from metal in the Federal Republic of Germany. The stylistic characteristics of West German "Teutonic" metal are captured by Herbst (2019, 2020a, 2020b) and Herbst and Bauerfeind (2021). Elflein (2017) provides a brief overview of the early West German metal scene, including bands and magazines.
} 
portrayed cultural production as socially manipulative and as a mass production process defined by rationalised organisational procedures to maximise profit, comparable to an 'assembly-line' (Adorno \& Horkheimer 1979, p. 163). Later research tended not to reject the recording industry altogether. Instead, the discourse shifted to a series of dichotomies aimed at elevating ethical, independent record companies over profit-driven global corporates (Mall 2018; Negus 2010, p. 2). In these comparisons, major labels are usually portrayed as villains, a "ruthless corporate "machine" that continually attempts to control creativity, compromises aesthetic practices and offers audiences little real choice' (Negus 2010, p. 36). Golding and Murdock (1996) describe the majors as 'instrumentalist', meaning that they influence artists to dance to their tune in their quest for profit. The record label's instrumentalist nature may also extend to the manipulation or exploitation of music consumers.

Major labels are generally understood to mean only the largest global corporations (nowadays Sony, Universal and Warner) with their sub-labels. In this understanding, all other companies are "independent" labels, regardless of size, structure and financial power. Indie labels are usually smaller businesses with few or no employees, less organisationally complex, closer to the scene and artists under contract, and primarily focused on niche genres (Denisoff 1975; Gillett 2011; Messick 2020; Netherton 2017). Ideologically, independent and major labels tend to differ in three areas: the profit-ambivalent, resistant and creative indies versus the profitoriented, conformist and conservative majors (Mall 2018, p. 460). Independent labels often present themselves in opposition to the established music industry and against commercial business goals to side with the scene. They depict their antiindustry principles by emphasising a moral standpoint, collectivism and belonging to a scene, and they place their own fandom and communal affiliation above commercial interest (see Strachan 2007).

Independent labels play an important role in the development of niche genres. Whereas anti-commercial genres like punk contradictorily drew on major labels, justifying it by the desire to reach the widest possible audience (see Waksman 2009, pp. 156-157), metal branched out into various sub-genres through independent labels early on. Newcastle-based Neat Records, for example, is seen as crucial to the global success of the New Wave of British Heavy Metal in the 1970s and 1980s (see Tucker 2015) because it created a decentralised infrastructure that enabled dispersed bands to reach national and international audiences without having to relocate to the capital (Waksman 2009, p. 186). At the same time, indie labels can be a powerful engine for regional scenes, much like a live music venue or regional fanzine (Waksman 2009, p. 187). Furthermore, independents are better suited to less financially attractive forms of music (Messick 2020, p. 3), which is why underground music has traditionally been built on a network of independent companies and DIY practices (Netherton 2017, p. 374). That by no means suggests niche genres like metal are uninteresting to major labels; if production and marketing costs are kept low or artists sell enough, niche genres are potentially lucrative.

Apart from these structural aspects, musical reasons, in the eyes of music fans and artists, speak for independent labels. Indies are said to interfere less with their artists' music yet with the drawback of smaller budgets (Messick 2020, pp. 2-3). But major labels, having recognised their expertise is less in the creative 
department, also tend not to meddle in the creative process and instead rely more on their strengths, which lie in distribution, retail and promotion (Negus 1999, p. 177). The claim that independent labels have closer relationships with their artists (Messick 2020, p. 26) is contested too. It is in the interest of each label to satisfy the artists' needs to increase the likelihood of receiving their best work in return (Hull et al. 2011, p. 200). Major labels have increasingly given autonomy to their subdivisions, allowing specialists in specific genres and sub-genres, who may be part of the scene and passionate about the music, to work with artists like independent labels do (Negus 1999, 2001).

Proximity to the scene is beneficial to the perception of indies. Independent companies are frequently described as community-oriented and driven by passion. In his study of contemporary metal indie record companies, Messick (2020) finds that label owners started their business to fill an existing void in the community and support bands and the scene. Kahn-Harris' (2007, p. 126) study concurs with this assessment, showing that record companies acting more in self-interest than the community's interest are rejected in metal. Messick (2020) finds another motivation for starting a metal label: being more personally involved in the community, sometimes leading from a volunteer or serious leisure activity (Stebbins 2009, 2017) to a larger business and possibly full-time work and employees. Strachan (2007, p. 255) similarly notes that micro-label operators are motivated by recognition and affirmation. Both Messick (2020) and Strachan (2007) agree that in many cases, running an independent label is not a lucrative venture but rather an extension of a fan practice, such as tape trading or journalistic writing, and thus a natural progression of everyday consumption and leisure activities. The process of producing and releasing music is an enjoyable activity for the small label operator, providing personal satisfaction and a sense of achievement (Strachan 2007, p. 255). For many independent label owners in these two studies, running their businesses is a sideline to their main job, and whether they make or lose money is of secondary importance: 'It's not profitable. Most years I just about break even. I do it because I love music... Most of these label owners can't live off of their labels alone, so they also have day jobs' (Messick 2020, p. 24).

Independent labels enable bands, in the words of Kerrang! author Howard Johnson, to 'fulfil the ambition of producing a record before fading back to join the ranks of fans' (as quoted in Waksman 2009, p. 187). In other words, independent labels may cater to the serious leisure activities of ambitious semi-professional artists and their niche audience. If this were true, then most artists in genres outside the mainstream would have to be classified as serious amateurs (Stebbins 2009, 2017) because major label support is unattainable. This view, however, undermines the achievements of independent labels, recording studios and production staff, not only of labels important in the history of popular music such as Atlantic, Motown and Stax, but also of the now professionally operating independent record companies in metal. Yet despite their essential role, indies are commonly seen as a stepping stone to a major label (Wells 2017). Artists hope for better production and dissemination structures that may earn them higher revenues (Messick 2020; Strachan 2007).

Generalisations and dichotomies between community-oriented independent businesses and profit-driven major labels are overly simplistic given that record labels 
and artists wishing to make a living from their music must function in a capitalist system, regardless of their principles. Hesmondhalgh (1996) and Lee (1995) find that independent labels must compromise idealistic principles with capitalist mechanisms to be effective and stay in business. Negus (2010, p. 43) warns against overromanticising independent record labels because most 'are making recordings not because of a commitment to an alternative cultural or political agenda, but... due to their commitment to the system and their own financial success within it'. However, this economic pursuit does not make record labels the enemy of artists and music fans. What Negus (2010, p. 64) proposes, drawing on the work of Bourdieu (1986), is to recognise all record labels as 'cultural intermediaries', as they are social mediators between bands and audiences and crucial to the production of culture, caring about music scenes as necessary for their success. Instead of forcing and manipulating, labels try to understand the audiences' desires and help artists fulfil them (see Hennion 1983). Negus (1999, p. 16) rejects the accusation of "instrumentalism" (Golding \& Murdock 1996), arguing that companies cannot set up and impose structures at will. Such a view 'neglects the many human mediations which come in between the corporate structures and the practices and sounds of musicians, most notably the work of the intermediaries of the music and media industries' (Negus 1999, p. 16). Record companies are essential institutions for the entertainment industries (Spracklen 2019). Their work is not limited to producing and selling culture to be consumed as leisure but involves mediating between the artists' creative intentions and consumer needs. The capitalist system in which this mediation takes place puts pressure on musicians and record labels alike and may require compromises between principles and economic viability.

\section{Krautrock and the Establishment of an Independent Music Industry}

Rock music came to West Germany in the 1950s through foreign radio stations and the cinema. The German music market was dominated by petty schlager, an apolitical and positive form of light popular music entertainment created to lighten the post-war sentiments of the population. Conservative, affecting but hardly innovative music represented the zeitgeist; the only exception was a thriving avant-garde countermovement in the arts (Reetze 2020, p. 76). With the growing popularity of rock'n'roll, the big, established record companies realised a market for rock music (Reetze 2020, p. 40). To exploit this emerging market, they produced German schlager interpretations of rock'n'roll, skiffle and beat. The results bore little resemblance to the British and US templates and, in most cases, were inferior copies of Anglo-American rock idioms mixed with schlager (Klüsener 1989).

Rock music was thriving in the United States and Great Britain in the 1960s and 1970s, strengthening the Anglo-American dominance in the record industry for years to come (see Negus 2001, pp. 7-12). In comparison, the German recording industry was disadvantageous for niche music. Music production was entirely in the hands of major companies, which hindered innovation and subcultural scenes. Independent labels, studios and record producers hardly existed for rock music in 
the 1960s, nor did adequate concert venues (Simmeth 2016, pp. 115, 198). Another structural disadvantage was that music managers were officially forbidden, as the Federal Employment Agency's artist department had a monopoly on managing musicians until the mid-1970s (Reetze 2020, pp. 214-215; Simmeth 2016, p. 208). Reports of bands that followed the rules and were "managed" by the federal agency provide insights into its lack of professionalism. Klaus Meine of the Scorpions once stated:

On some Saturday, we had a gig in the south and wanted to play somewhere on the way back. The agency arranged a gig for us on Sunday afternoon at Hotel Achtermann in Goslar... We set up our stuff and realised that we had landed ourselves at the annual general meeting of the local tennis club. (Halupczok 2010, p. 33; translation)

The monopoly was supposed to protect artists from exploitation, but such a dilettante music management did the opposite, disadvantaging German rock bands (Klüsener 1989). These unfavourable structures, however, provided space for exploration beyond Anglo-American standards, which was pivotal for the emergence of an original German form of rock music in the late 1960s and early 1970s (Simmeth 2016). ${ }^{2}$

If one event can be named that marks the beginning of West German rock music outside the grasp of the established, schlager-centred major labels, it was the International Essen Song Days in September 1968, where early krautrock bands played their first concert to a broader audience. Music journalist Rolf-Ulrich Kaiser organised this music festival, inspired by the Monterey Pop Festival of 1967. In the spirit of "Summer of Love", he conceived the festival as a non-profit event, realised through generous funding from Essen's Department of Youth (Adelt 2016, pp. 8-9). Despite significant financial losses, the festival was an important springboard for countercultural rock music in Germany (Adelt 2016, pp. 8-9; Simmeth 2016, pp. 94-110).

Krautrock is the name attributed by the British media to rock music from West Germany, produced from the late 1960s to the late 1970s. Krautrock bands did not have a coherent sound, yet shared a left-wing, DIY attitude and experimented with recording technologies to create an experimental, sometimes "cosmic" sound that was deliberately different from Anglo-American rock aesthetics (Adelt 2016; Simmeth 2016). The first krautrock albums were released in 1969 by German branches of international major labels like US Liberty Records. In 1970, Rolf-Ulrich Kaiser opened Ohr (Ear) as the first independent record label for rock music. It was distributed by the German branch of the Swedish major label Metronome and intended to support German progressive rock through a professional music production and distribution service (Simmeth 2016, pp. 216-217), from which numerous bands like Tangerine Dream, Ash Ra Tempel, Guru Guru and Embryo benefitted. Soon, distributor Metronome limited Ohr's activities due to the high number of releases,

\footnotetext{
${ }^{2}$ For a detailed account of the recording industry infrastructure in West Germany in the 1960s and 1970s, see Herbst (2022).
} 
prompting Kaiser to open a second label, Pilz (Mushroom). Within the first two years, the labels sold a combined 250,000 copies but made no profit because of high production, touring and marketing expenses (Adelt 2016, p. 91; Reetze 2020, p. 271). Kaiser's vision was to increase the market share of domestic bands from less than one per cent to ninety per cent (Reetze 2020, p. 271), which he intended to realise by signing many bands and massive advertising campaigns (Stubbs 2014, pp. 392-393). In 1973, Kaiser founded a third label, Kosmische Kuriere (Cosmic Couriers), to promote his vision of a 'deterritorialized, postnational cosmological identity, which involved the consumption of psychedelic drugs' (Adelt 2016, p. 83). At this point, two main employees, Bruno Wendel and Günter Körber, left Kaiser to open their own labels for German progressive rock, Brain and Sky. They released the first albums of hard rockers Scorpions and Accept, fostering the early careers of bands that would become the figureheads of German proto-metal (Herbst 2019). Kaiser became a laughing stock for his LSD-influenced marketing campaigns and eventually had to declare bankruptcy in 1975 . Even so, Kaiser's crucial role as a promoter for countercultural rock music should not be underestimated (see Simmeth 2016, pp. 223-224). His three record companies were the first independent labels giving full support to progressive rock music regardless of commercial success. The top sellers at Ohr and Pilz sold about 15,000 records, but the average release was only between 1000 and 3000 (Reetze 2020, pp. 227-229).

Kaiser promoted countless progressive German rock bands, and with his labels, he also paved the way for independent recording studios and self-employed audio engineers and producers of whom Conny Plank and Dieter Dierks were the most important, working with all relevant krautrock labels. Both had in common a disinterest in commerce and a distrust of the major labels. Besides supporting progressive rock, their role as mediators in the recording industry must be noted. They set up their own record labels and publishing companies to gain business contacts that gave their clients a better negotiating position with labels, and they occasionally recorded bands for free (Reetze 2020, p. 259). While Plank already passed away in 1987 and thus had less impact on German metal, Dierks was influential for producing the first records of the proto-metal band Accept and most Scorpions albums.

Despite disagreements, most collaborators have acknowledged Kaiser's role in enabling German countercultural rock music. Dieter Dierks once stated: 'He was the visionary who allowed all these musicians to realise their music in the studio and then sell it to a not exactly friendly industry' (Simmeth 2016, p. 224; translation). Musician Klaus Schulze similarly acknowledged his essential role for rock music:

Kaiser was already working according to the American principle. And we didn't understand it. We were simpletons somewhere in terms of business and were happy to have finished a record. But we didn't know anything about advertising and promotion, neither about its importance nor how it works... If Kaiser hadn't promoted the music, it probably wouldn't exist today. (Simmeth 2016, p. 223; translation)

Kaiser was affected by the tension between operating popular music labels and economic viability. Releasing music and promoting it allowed music to be heard and artists to spread their message. However, it went against the countercultural, 
anti-consumerist spirit of the time, leading to accusations of inauthenticity due to conspicuous working arrangements with the established industry like major label distributors (Simmeth 2016, pp. 194-195). Kaiser tried to resolve this conflict by choosing independent producers like Plank and Dierks and not interfering in the artistic process (Reetze 2020, p. 279) to support an "emancipated music" that liberated people and enabled them to be creative (Simmeth 2016, pp. 194-195). After all, he reasoned, emancipating pop music also required the music industry to distribute the message, and making money from music did not contradict the countercultural spirit if the intentions were genuine (Simmeth 2016, pp. 194-195).

Despite the chaotic workings of krautrock, the genre was pivotal for preparing the German music industry for countercultural popular music. Since krautrock largely disappeared before metal emerged in the 1980s, there are few direct links, but metal still benefitted from krautrock's achievements. Between krautrock and metal, punk became popular in Germany from around 1977 and the Neue Deutsche Welle ("new German wave") between 1979 and 1983 (see Adelt 2016, pp. 161-166). Both absorbed krautrock's influence in DIY aesthetics, building on the new music industry infrastructure, and were relevant for German metal, not so much musically but in developing a market for music made in Germany.

\section{The Formation of West German Metal and Its Record Companies}

German metal already existed in a preliminary form in krautrock and hard rock. "Pop Rock in Concert", a two-day festival in Dortmund's Westfalenhalle in December 1983 with performances by Judas Priest, Iron Maiden, Ozzy Osbourne, Def Leppard, The Michael Schenker Group, Quiet Riot and the Scorpions (Elflein 2017; Mühlmann 2008; Schmenk \& Krumm 2010), triggered a national movement and made German metal a distinct style. The festival received considerable media attention; it was the first metal concert broadcasted by German national TV and covered in metal magazines like the Dutch Aardschok and German Rock Hard. The German Metal Hammer was founded as a special issue for this festival (Schmenk \& Krumm 2010 , p. 80). The event sparked a surge of metal bands in the following years so that in the late 1980s, the sheer quantity of releases was already lamented because it was difficult for fans to identify high quality (Kühnemund 1988a; Penzel 1989). These releases were made possible by many record labels, with Steamhammer, Noise, Nuclear Blast and Century Media being the most impactful and long-lasting, but not the only ones.

The small record labels emerging had different motivations. Some were founded to support a band by giving them a record deal when no other company did (see also Messick 2020). For example, Axel Thubeauville, a record store owner, opened Earthshaker Records in 1983 to help Steeler obtain a record deal. He subsequently discovered Warlock and Doro Pesch. With his various sub-labels, including Shark, Bonebreaker and T\&T Records, he introduced Sepultura, Stratovarius and Virgin Steele to the German market, which he distributed through Belgium Mausoleum and German Noise, not only making them available in Germany at affordable prices but also jumpstarting their careers in Europe (Gehlke 2017, pp. 401-402; Schmenk \& 
Krumm 2010, pp. 208-209). Two other labels originated to release albums for a specific band: No Remorse Records was founded in 1988 by Metal Hammer editor and record store owner Charly Rinne to sign Blind Guardian (Schmenk \& Krumm 2010, pp. 122), and Aaarrg Records was founded in 1986 by Thubeauville's go-to producer and Mekong Delta bassist Ralph Hubert to sponsor Holy Moses (Schmenk $\&$ Krumm 2010, p. 197). Focusing more on production than on managing his artists, with Hubert stressing that he placed production quality above profit (Neudi 2017), Aaarrg Records soon went bankrupt in 1989 and was acquired by Thubeauville. Thubeauville's labels eventually failed too and were sold to Karl-Ulrich Walterbach, owner of Noise Records, in 1998 (Gehlke 2017, pp. 401-402). Another small label with limited impact but a great presence in metal magazines was GAMA Music Publishing, founded in 1980 by Günther Marek and Peter Garattoni. Like Ralph Hubert, they were motivated by economic reasons to operate a label to utilise their recording studio Spygel and have an additional income besides their band Eulenspygel (Hilbig 1985). Yet another short-lived label with some influence was Wishbone Records, opened in 1982 by former PolyGram import manager Ferdinand Köther, as a distributor, importer and retailer of metal releases. Apart from original productions that launched careers like those of Germany's Avenger/Rage, the German scene benefitted from Wishbone because it imported the first Metallica releases and other foreign records produced by British Neat and American Shrapnel and made them widely available in German record stores. Wishbone went out of business in 1990 due to high production costs (Krumm 2012, pp. 59-62).

Of the four big German metal labels-Nuclear Blast, Century Media, Noise, Steamhammer-founded in the 1980s, Steamhammer is perhaps the least known internationally, but its contribution to the scene cannot be overstated. Manfred Schütz opened a record store in Hanover in 1974, intending to promote progressive German rock bands when British and US-American artists dominated the market (Mader et al. 1998, p. 14). The first German act Schütz produced in 1978 was a punk band. From 1982 onwards, Schütz concentrated on importing records from foreign labels, which soon became more work than one person could handle. He thus decided to close his record stores and focus on original and licensed releases. With his 1984 founded distribution company SPV, he imported Metallica, Slayer, Megadeth, Anthrax, Venom and Raven for the German market (Mader et al. 1998, pp. 15-16). Contrary to the common practice of re-releasing, which meant a later availability of an imported album, SPV made international agreements that allowed simultaneous releases to give metal fans in Germany the same dates as British and US-American fans (Rinne 1984). According to Schütz, the first German metal bands after "Rock Pop in Concert" emerged during summer 1984. His newly founded label Steamhammer Records had its first signings with the thrash bands Sodom and Destruction. SPV was the international distributor for Steamhammer and its competitor Noise, making it the most important metal distributor in Germany (Mader et al. 1998 , p. 14). The distribution success enabled Steamhammer/SPV to make unconventional and unprofitable signings without risking bankruptcy (Mader et al. 1998, p. 14) and to produce records that were not commercially successful but of historical value to the metal genre (Mader et al. 1998, p. 18). This support of the metal community is reflected in an early interview statement by A\&R manager Jutta Kestner: 
Of course, business things also play a role in the label, there's no denying that. But we also do this because we simply enjoy producing young, fresh and undiscovered bands that may come out bigger one day. We see our promotional work primarily as long-term development work to achieve the best possible results together with the bands. In this sense, we also support the bands signed to us wherever possible and do not immediately drop a group if the desired success does not materialise or takes a long time. Perhaps this is one of the main differences between SPV and the big industrial companies. (Rinne 1984, p. 67; translation)

This quote, representing similar statements by other German metal label employees, follows the general trend of independent labels to position themselves against the established music industry (see Strachan 2007). Furthermore, similar to RolfUlrich Kaiser engaging independent producers in the krautrock era (Reetze 2020, p. 279), Steamhammer/SPV preferred not to operate recording studios and instead employed freelance specialist rock and metal producers like Kalle Trapp with his Karo recording studio (Herbst 2019).

The histories of Steamhammer/SPV and Noise are closely intertwined. Not only did SPV distribute Noise records, but the two labels also competed for German bands, leading to a constructive rivalry that jumpstarted the careers of the four well-known "Teutonic thrash" bands—Kreator, Sodom, Destruction, Tankard—and power metal bands like Helloween. Noise was founded in West Berlin in 1983 by Karl-Ulrich Walterbach, who had previously run a punk venue and released punk records with his label Aggressive Rockproduktionen (Gehlke 2017, pp. 35-36). When the punk boom ebbed in the early 1980s, Walterbach developed a passion for thrash music:

I had to dedicate myself to thrash because this genre impressed me a lot-with Slayer, Metallica and what Metal Blade had released on early albums. Here at home, there was nothing comparable yet. I was desperately looking for any bands that made noise and sounded metal. With a lot of effort, I found Kreator and Tankard. Manfred Schütz from SPV had already signed Destruction and Sodom... Since Kreator were still very young at that time, you couldn't expect much from them. They had the same spirit as me: there was a new form of music, and we thought it was great. We wanted to do something with it. (Hesse 2006, p. 27; translation)

Although Walterbach was inspired by US thrash, he preferred signing German bands and supporting them in developing their own style (see also Herbst 2021a). Since quality went over quantity, he offered bands professional productions in Harris Johns' Music Lab, his own Sky Trak studio and various rented studios in Germany (e.g., Helloween in Frank Bornemann's Horus, Hanover) and abroad (e.g., Kreator in Randy Burns' Music Grinder, Los Angeles). Walterbach arranged for international distribution and costly overseas tours, a strategy that made Helloween, Kreator and Celtic Frost internationally successful (Klemm 1987). Rarely did Walterbach sign a band that had previously been with another label, as he believed in discovering and mentoring budding artists (Gehlke 2017, p. 279). Noise appealed to 
the German and European scenes with this business philosophy, as Blind Guardian singer Hansi Kürsch stated: 'You could feel that in comparison to American/British independent labels like... Music For Nations, Metal Blade, or Neat, that this new label was literally closer to the scene' (Gehlke 2017, pp. 9-10). Whereas some of Walterbach's early bands expressed feeling betrayed, as did Rage, most were grateful for the chance that launched their careers (Gehlke 2017). Walterbach distrusted major labels and avoided collaborations wherever possible. He only briefly collaborated with BMG (Germany), CBS/Epic (USA) and EMI (UK) between 1989 and 1994 to give his top bands Helloween, Kreator, Celtic Frost and Running Wild more support than an independent label could offer, putting the bands' interests above his desire to retain control (Gehlke 2017, pp. 139, 197, 361-380). After their collaboration, British major label Sanctuary/EMI attempted to poach Noise's top bands, leading to court cases that prevented the artists from releasing new albums for several years, which ultimately prompted Walterbach to sell his label to Sanctuary in 2001 (Gehlke 2017, pp. 425-442).

Steamhammer/SPV and Noise were not the only, or even the first, independent metal labels, but they were crucial in making foreign records available in Germany, giving fans direct access without needing to trade tapes. Moreover, they were patrons of the German metal scene, sponsoring domestic bands they believed in, some of which became international success stories, while others never gained wider attention. Both labels influenced the music trade, especially in that they made retailers realise German metal music's potential, according to Hansi Kürsch: 'When these two companies started signing bands, the local record stores in Germany discovered the potential of the metal scene and, in doing so, increased the dynamics of the metal movement drastically' (Gehlke 2017, p. 10). Steamhammer and Noise prepared the ground for the second wave of metal labels to come.

Nuclear Blast and Century Media, probably the best-known German metal labels today, were founded with a similar community-oriented business philosophy a few years after Noise and Steamhammer. Michael Staiger, who ran a metal fanzine, started a mail-order business in his bedroom in 1985 called Misthaufen Distribution (Dungheap Distribution) (Mineur 2007) to expand his fanzine practice by helping metal fans obtain their favourite music: 'When I started my first mail-order business in the 1980s, I wanted to bring people closer to the music I liked. My wish was that everyone could listen to the records I liked to listen to myself' (Ahlig \& Zahn 2013, p. 61; translation). Inspired by a US trip, Staiger founded Nuclear Blast Records in 1987 in rural Donzdorf to support music he was passionate about: 'What drove me was not the hope of big money, but the pure desire to be able to release and distribute music I loved so much' (Ahlig \& Zahn 2013, p. 60; translation). Substantial personal loans to afford early record productions (see Engelking 2007) paid off in the early 1990s, leading to the company's expansion to include its first employees. To this day, Staiger emphasises still running his label from a community-oriented perspective, supporting artists and supplying fans:

The fans see our releases, our advertising. Many think it's great, others rail against commerce and trends and think we're telling bands what to do. Some think it's just a business relationship_-it may be on paper, but the 
reality is different. We are friends with all the bands, and close relationships develop between staff and musicians, especially with the big bands like Slayer and Nightwish. With [German] Avantasia, Blind Guardian or Edguy anyway, we've known each other for a long time. People think it's good when we bring new bands to the fore... We really only release bands that we like. (Weckmann 2017, p. 39; translation)

Another indication that Nuclear Blast genuinely wishes to collaborate with bands is that artists are involved in the label's management, as Staiger explained: 'It has advantages to have musicians in the team because they know both sides and have understanding for difficulties in some necessary decisions' (Mineur 2004c, p. 53; translation). Community-oriented intentions also showed in Staiger helping fellow tape-trader Robert Kampf open his label Century Media (Schmenk \& Krumm 2010, p. 223), which soon became Nuclear Blast's main competitor. Since Nuclear Blast never had its own studios, it hired producers worldwide who suited the artists' style.

Century Media's beginning was similarly humble as that of Nuclear Blast when Robert Kampf founded the label in Dortmund in 1988 to release the debut of his band Despair, as the musicians did not want to be influenced by another company (Krumm 2012, pp. 16-19). Kampf repeatedly stated in interviews, 'I think it's very important that the label makers are also actually fans of the music' (Schmenk \& Krumm 2010, p. 77; translation), a philosophy to which he committed throughout his career when signing bands (Krumm 2012, p. 174). Its second signing, death metal band Morgoth from nearby Meschede, was a considerable success, allowing the label to grow and sign more underground bands, as did its later successes with Swedish Tiamat and Italian Lacuna Coil (Krumm 2012). Unlike Noise, Century Media did not limit itself to releasing debut albums and developing bands from scratch, signing bands from smaller labels as well to help them grow and make them accessible to the broader metal community (Krumm 2012, p. 74). Century Media, just as Nuclear Blast representatives, has often emphasised the supportive mission towards its signed artists and the metal community (see Krumm 2012). The fact that bands tended to stay with or return to the label may be seen as evidence of a mutually beneficial collaboration. British Paradise Lost is one of the bands switching major label EMI for Century Media because they valued working with a company interested in the metal scene and balancing economic with artistic considerations (Krumm 2012, p. 167). In the early days, Century Media relied on local production infrastructures, such as the Woodhouse recording studio with producers Siegfried Bemm and Waldemar Sorychta, and distribution by SPV (Herbst 2019; Krumm 2012).

Although Century Media and Nuclear Blast may have promoted fewer domestic metal bands than the first wave of metal labels-Noise, Steamhammer and the many smaller companies - they must be acknowledged for having become home to many high-profile German bands (Gehlke 2017, p. 427). 
Table 1 Number of releases per label

\begin{tabular}{|c|c|}
\hline Record label & Number of releases \\
\hline Noise & $25 \%(29)$ \\
\hline Steamhammer & $15 \%(17)$ \\
\hline $\mathrm{RCA}^{\mathrm{a}}$ & $9 \%(10)$ \\
\hline Self-released & $9 \%(10)$ \\
\hline Vertigo $^{\mathrm{a}}$ & $7 \%(8)$ \\
\hline Brain & $4 \%(5)$ \\
\hline Harvest (EMI) ${ }^{\mathrm{a}}$ & $4 \%(5)$ \\
\hline Century media & $3 \%(3)$ \\
\hline Elektra $^{\mathrm{a}}$ & $3 \%(3)$ \\
\hline Metronome $^{\mathrm{a}}$ & $3 \%(3)$ \\
\hline $\operatorname{MSA}(\mathrm{RCA})^{\mathrm{a}}$ & $3 \%(3)$ \\
\hline No remorse & $3 \%(3)$ \\
\hline Aaarrg records & $2 \%(2)$ \\
\hline Earthshaker & $2 \%(2)$ \\
\hline Epic $^{\mathrm{a}}$ & $2 \%(2)$ \\
\hline Devil's game & $1 \%(1)$ \\
\hline $\mathrm{EMI}^{\mathrm{a}}$ & $1 \%(1)$ \\
\hline Intercord $^{\mathrm{a}}$ & $1 \%(1)$ \\
\hline Mausoleum & $1 \%(1)$ \\
\hline Nuclear blast & $1 \%(1)$ \\
\hline Philips (Deutsche Grammophon) ${ }^{\mathrm{a}}$ & $1 \%(1)$ \\
\hline Scratch records & $1 \%(1)$ \\
\hline SL records & $1 \%(1)$ \\
\hline WEA $^{\mathrm{a}}$ & $1 \%(1)$ \\
\hline Wishbone & $1 \%(1)$ \\
\hline
\end{tabular}

Companies marked by ${ }^{\text {a }}$ are major labels; numbers in parentheses indicate the absolute number of releases

\section{Music Production and Distribution Infrastructure of Early Metal in West Germany}

For a comprehensive picture of the production industry for German metal that goes beyond the selective view presented in the literature, the music release database Discogs was analysed. Thirty-four bands of national standing were identified with the help of Encyclopaedia Metallum, meaning they were discussed in mainstream metal magazines of the time, Metal Hammer and Rock Hard. This selection process resulted in a corpus of 115 albums released up to 1989 that, although not representative of all metal releases, gives an approximate overview of the release structure in Germany. Overall, two of the main findings were: (1) certain record companies, studios and production staff were central to the early German metal scene, (2) there was also a broad range of companies and individuals not covered in the existing literature. 
Regarding record labels (Table 1), the data shows that the two biggest companies, Nuclear Blast and Century Media, do not yet play a significant role in the early German scene and together account for only $4 \%$ of the releases. This low ratio can be explained by their relatively late founding years (1987 and 1988) and the fact that they prioritised foreign death metal. The leading labels for German metal were Noise $(25 \%)$ and Steamhammer (15\%), which have concentrated on domestic bands since the early 1980s and grew with the successes of Kreator, Destruction, Sodom and Helloween. On closer inspection, there are several links to Germany's earlier krautrock history (see also Elflein 2017; Mader et al. 1998). Apart from a small number of metal releases on krautrock label Brain (4\%), most of the major label releases, $33 \%$ in total, are by former krautrock bands: Lucifer's Friend, Accept/ U.D.O., the Scorpions and Victory/Fargo. Only four metal bands without a krautrock history could obtain a major label contract in the 1980s: Warlock and Doro Pesch's solo band with Vertigo, Axxis with EMI and Pink Cream 69 with Epic. As the data suggests, German metal had few direct benefits from the krautrock record label network of the 1970s; neither independent krautrock labels nor major labels tended to sign metal artists. Instead, new labels specifically founded were crucial to the German metal release network. Although the corpus is incomplete, it indicates that many labels-25 in this corpus-were involved in the developing scene.

Despite numerous record labels existing, the distribution structure was not particularly diverse. $53 \%$ of all metal releases were distributed by SPV as the distributor for Steamhammer, Noise, Century Media, Nuclear Blast and most smaller companies, $5 \%$ by the small indies themselves, and the remaining $42 \%$ by the major labels' distribution arms. Given that the major companies released $33 \%$ and distributed $42 \%$ of all productions, several indie labels likely had distribution deals with the majors, indicating that the established industry recognised some economic potential in the burgeoning German metal.

Recording studios and personnel tend to be overlooked in metal scholarship and journalism. The studied literature highlights Harris Johns' Music Lab (Noise), Siegfried Bemm's Woodhouse studio with in-house producer Waldemar Sorychta (Century Media), Horus, Sky Trak and Caet studios, as well as Noise engineer Horst Müller. The corpus analysis shows a more differentiated picture. Although the production specifics could not be identified in all cases, the records were made in at least 38 studios with the help of more than 55 producers and engineers. In terms of studios, the most used facilities were Dieter Dierks' studio (16\%), one of the two main studios of the krautrock era. It was followed by Harris Johns' Music Lab (13\%), Frank Bornemann's Horus (11\%), Kalle Trapp's Karo Musikstudio (7\%), Caet Studio (6\%), Soundhouse (4\%), and Delta, Sky Trak, Maschen, and Wahn studios (3\% each). These account for two-thirds of the releases and can thus be considered the primary metal studios of the time. Against the background that 29 other studios were also used, metal music production did not likely revolve entirely around production centres and partly relied on either non-metal studios or semi-professional services. The number of studios exceeds the 18 sites Metal Hammer listed in 1989 (Kerzel 1989) and contains different studios, suggesting that numerous facilities contributed to the emerging scene. Consequently, the list of recording personnel is diverse. The top producers were Harris Johns (11\%), Dieter Dierks (8\%), Kalle Trapp, Michael 
Wagener, Tommy Hansen (6\% each), Dirk Steffens, Horst Müller (5\% each) and Ralph Hubert (3\%). The rest were a mixture of krautrock recordists (e.g., Conny Plank, René Tinner), label owners (e.g., Axel Thubeauville, Karl-Ulrich Walterbach, Ferdinand Köther, Peter Garattoni), international big-names (e.g., Mark Dodson, Joey Balin, Alex Perialas, Chris Tsangarides, Roy Rowland, Randy Burns, Michael Wagener) and many lesser-known engineers. This finding indicates that most German metal productions were built on a semi-professional network of German companies and freelancers; only a few bands received enough funding to work with top international names (e.g., Kreator, Warlock, Doro Pesch, Accept, U.D.O., Sinner, Holy Moses). Overall, the data shows that the network of independent recording studios and recordists, which had begun through krautrock in the 1970s, had grown, enabling semi-professional and small-scale professional music production operations essential for an emerging and growing German metal scene.

\section{Evaluating the West German Rock and Metal Industry}

Since its emergence in the late 1960s, the German rock and metal industry has developed from a relatively weak music production economy compared to the US and UK to one of the main locations for international record production. Back then, countercultural rock music had little infrastructural support because major record companies only promoted schlager-infused rock'n'roll, and there were no independent labels worth mentioning for niche popular music and privately owned recording studios. Within a few years, krautrock established this infrastructure in the 1970s. Small independent record companies helped bands like Tangerine Dream to international fame, but overlooked is that the vast majority of artists were allowed to record albums even if they did not yield a commercial return. In their too ambitious and idealistic endeavour, the three primary labels, Rolf-Ulrich Kaiser's Ohr, Pilz and Kosmische Kuriere, went bankrupt within six years. Supporting German progressive rock music to establish a left-wing counterculture and not bow to the demands of capitalist society was not sustainable. After Kaiser went out of business, many krautrock artists opened their own labels to continue releasing music, about one hundred labels in 1977, most of them eventually ending in financial disaster (Simmeth 2016, p. 210). The lack of economically viable record companies for rock music made krautrock disappear from the scene towards the end of the decade.

When metal began to flourish in West Germany in the mid-1980s, it could build on the achievements of krautrock. Just as anyone could start a fanzine or fan club, anyone could open a record company or recording studio and contribute to the metal community this way. As the previous analysis showed, many individuals took advantage of the new opportunities. According to record label Neat biographer John Tucker (2015, p. 11), there were only five notable independent record companies in the UK during the prime of the New Wave of British Heavy Metal (approx. 1979-1983). The German scene benefitted from a much larger number of labels of diverse sizes.

The motivations for opening these companies are consistent with those described in the literature on independent labels (Messick 2020; Strachan 2007). Many 
emerged naturally as an extension of a music-related practice like tape trading or distribution, record store retailing or music performing and production. Some arose out of fandom, trying to support the careers of promising artists who could not otherwise find a label. Others like GAMA have been accused of trying to cash in on the metal trend (Neudi 2017) by running a label to utilise their recording studio, but the same has been said about Neat (Tucker 2015, pp. 145, 188, 325), which does not diminish their role for the New Wave of British Heavy Metal. Most labels, including the larger ones like Steamhammer, Century Media and Nuclear Blast, have credibly emphasised their community-oriented principles. Only a few have been able to juggle these communal ideals with their economic necessities, and so over time, most labels closed or were taken over by larger companies. Of the labels studied, only Nuclear Blast is still independent, while Century Media was the last one being merged into Sony Music in 2015.

A communal spirit characterised early German metal, so individuals saw their involvement in music as an extension of their fan practice rather than a profession (see Messick 2020; Strachan 2007). Hardly any professionals were in the scene when it was formed with its various industries like the record business or journalism. Clear distinctions between fans, musicians, recordists, journalists and record business entrepreneurs barely existed. To give a representative but incomplete list: Steeler vocalist Peter Burtz was journalist and editor for Metal Hammer; Metal Hammer editor Charly Rinne ran No Remorse Records; Aaarrg owner Ralph Hubert was Mekong Delta bassist and a metal producer; Eulenspygel musicians Peter Garratoni and Günter Marek operated a recording studio and their GAMA label; Robert Kampf founded Century Media to release music by his own band Despair; fellow Despair guitarist Waldemar Sorychta became one of the main record producers of early German metal; Nuclear Blast founder Michael Staiger was an avid tape-trader and mail-order-operator who gave German metal fans access to foreign releases; Eloy guitarist and vocalist Frank Bornemann owned one of Germany's main metal recording facilities, Horus; Tommy Newton of Fargo/Victory ran the Area 51 recording studio; founders of Rock Hard magazine like Götz Kühnemund also ran the fan club Metal-Maniacs-Germany. While this lack of clear affiliation sometimes caused problems with objectivity, especially in journalism, it prevented hard barriers between artists, businesses and media, and it facilitated interaction in the interest of the wider scene. This blurring of roles seems to be typical not only of German metal. Autobiographies of other labels show that US Metal Blade's Brian Slagel began as a tape trader and fanzine writer (Slagel 2017), US Megaforce's Jon Zazula as a tape trader and record store owner (Zazula 2019), and British Peaceville's Paul Halmshaw as a punk musician (Halmshaw 2019). Nevertheless, all the indications are that fans and lay practitioners formed metal communities in the 1980s and laid the foundations for a significant industry to come.

For many record label owners, running their business meant considerable personal investment, as was stressed in interviews and covered in metal journalism. Messick's (2020) study may have found some contemporary metal indie label operators declaring their losses as hobby expenses, but for the majority, producing music in a pre-digital era involved substantial costs threatening their owners' existence, including larger labels like Century Media (see Krumm 2012, pp. 41-45). In this 
regard, the German labels were no different from their British and American counterparts; the autobiographies of Megaforce founder Jon Zazula (2019) and Peaceville founder Paul Halmshaw (2019) describe similar concerns that eventually let them to sell their labels. Compared to those major financial crises, broken marriages (see, e.g., Mader et al. 1998, p. 15) are a less drastic consequence, but still a personal loss resulting from business ventures.

Kerrang! author Howard Johnson described the function of independent labels as allowing amateurs to produce a record and become semi-professional or even professional for a while before returning to the ranks of fans (see Waksman 2009, p. 187). Despite the polemic nature of this statement, it is demonstrably not entirely wrong. Interviews in metal magazines suggest that most German metal artists could not make a living from their music. Of the four popular "Teutonic thrash bands", only Kreator were able to live from music (Himmelstein 2001), not so Sodom (Kühnemund 1988b), Destruction (Jaedike 2001) and Tankard, the latter describing themselves as a 'semi-professional hobby band' (Jaedike 2004, p. 94). Other notable exceptions were Helloween (Stratmann 2015), Running Wild (Klemm 1985) and Grave Digger (Kleiner 1986). Century Media founder Robert Kampf stated in a 2004 interview that to make a living from music, metal bands needed 50,000 copies sold per album (Stratmann 2004). He also made public that the label's top albums in the 1990s, such as Tiamat's (1994) Wild Honey, sold 60,000 copies in Germany (Krumm 2012, p. 44), indicating very few releases allowed their artists to become fully "professional". Similarly, British Peaceville owner Paul Halmshaw (2019, p. 149) described how not even his label's top artists like My Dying Bride could draw a monthly salary from their record sales, nor could Scandinavian bands like Soilwork (Buffo 2002). These findings suggest that most metal artists needed to generate other sources of income like teaching or had to pursue their serious leisure careers (Stebbins 2009, 2017) alongside their non-music-related day jobs. This finding supports research criticising the widespread belittling of semi-professional music careers, seeing them as merely a stepping stone to a full-time music career (see Finnegan 1989; Miller 2018).

In terms of music studios and record producers, German metal seemed to echo the earlier krautrock tradition, where the leading figures Conny Plank and Dieter Dierks placed artists above commercial interests (Reetze 2020, p. 259; Stubbs 2014, pp. 337-338). The Horus Sound Studio in Hanover, founded by the krautrock band Eloy, was one of the central German rock and metal studios from 1979. After Eloy broke up, the studio became Frank Bornemann's company, which he saw as a fullservice enterprise with talent scouting, artist development and production management. An explanation of his business philosophy sheds light on German metal in the 1980s:

Especially newcomer bands still have a hard time in Germany. There are hardly any suitable contact points for young bands in our country, only a few companies have the necessary know-how in all aspects of the biz, which is needed if a new group wants to progress. Seriously, much is still left to chance. Lack of competence is still a negative feature of the German music business, apart from the very few internationally experienced managers and producers. These 
few would be hopelessly overburdened if they were to take intensive care of promising talents in addition to their day-to-day business. An infrastructure of the kind that has grown in the USA or England over decades is still largely lacking in Germany. That is where we want to start. When we decide to work with a band, we accompany them intensively through all phases of their further development, help, advise, build up and try, as far as possible, to remove all difficulties from the band's path. We are musicians ourselves and therefore always approach the work from a musician's point of view. (Klüsener 1988, p. 30; translation)

Not being a charity organisation, the studio was required to be economically viable. Hence, besides a few smaller bands like Kingdom/Domain, Scanner or Steeltower/Heavens Gate, mainly Germany's top metal bands like Helloween, Kreator, Gamma Ray, Rage and Sodom recorded albums at Horus. Other notable producers, Harris Johns with his Music Lab and Siegfried Bemm with his Woodhouse, were decisive for the early successes of Noise and Century Media, respectively. Research on early German metal producers (Herbst 2019, 2021a, 2021b) and label documentaries (Gehlke 2017; Krumm 2012) show their commitment to the German metal scene, with little regard to commercial considerations beyond what was necessary to stay afloat-much in the tradition of earlier krautrock producers.

Besides the alleged lack of professional recording studios and producers in Bornemann's view, managers were widely missing, which has been repeatedly highlighted as a structural disadvantage for German rock musicians in the 1970s krautrock era (Reetze 2020, pp. 214-215; Simmeth 2016, p. 208) and still in 1980s metal music (Klüsener 1989). Managers have sometimes been portrayed as manipulative and exploitative agents in the music industry (Rogan 1988). However, they are also acknowledged as helpful advisers for artists, as they devise career strategies, settle disputes with record labels, organise concerts and promotional events, and allow artists to focus on their music (Negus 2001, p. 41). Bogdan "Boggy" Kopec and Ralf Christian "Limb" Schnoor were the two main metal managers of the 1980s with a great impact on the professionalisation of German metal. For bands like Helloween, Kreator, Sodom, Running Wild and Rage, they organised tours (Krumm 2011, pp. 363-364; Schmenk \& Krumm 2010, p. 85), drove the bands, were their fan club presidents and took care of their royalties (Gehlke 2017, pp. 148-149). Sodom once explained the advantages of management as follows: 'Before we got management, we had to do everything ourselves. That was a really hard time. We paid a lot of money, were often on the road and had to set up everything ourselves at shows' (Glaub 1995, p. 33; translation). Modern artists must be entrepreneurs (Wade Morris 2014); Netherton (2017) even speaks of an 'entrepreneurial imperative' for contemporary metal bands that places entrepreneurship at the centre of artistic identity. In contrast, managers in the 1980s and 1990s freed metal bands from this administrative burden.

Negus $(1999,2001,2010)$ has advocated for record labels to be acknowledged as 'cultural intermediaries' (see also Bourdieu 1986) and enablers of cultural production. Overall, the companies studied worked for their artists and audiences. Just as their international counterparts, Metal Blade (Slagel 2017), Megaforce 
(Zazula 2019) and Neat (Tucker 2015), many German labels started by importing foreign records to offer them at affordable prices. As most of these labels were genuinely interested in developing musical careers, they soon began signing bands to foster promising domestic talents. What distinguished German companies from the Anglo-American scenes was perhaps the way they perceived their businesses. For example, instead of competing with major labels, British Neat Records saw itself as discoverer of bands for the major label Music Corporation of America (MCA) (Tucker 2015, p. 117; Waksman 2009, pp. 187-188). Jon Zazula revealed in his autobiography that Megaforce's business philosophy was much the same:

We always wanted them [Metallica] to be on a major label. We wanted all our bands to, but hoped they would stay with us for management and direction... we felt if we had a major label attached [to] it [, it] would only help get the band bigger. The touring, promotion, advertisements, record distribution, and getting the bands on the radio, it would just elevate the bands and skyrocket them to success. (Zazula 2019, p. 11)

Metal Blade took a similar approach according to Brian Slagel's memoir:

I had no qualms with Slayer signing to a major label because I knew-everybody knew-it was going to happen sometime... A major label has the ability to offer a group the kind of money that young men can't refuse, and it's great for those bands to get that opportunity. I was just a small label with a few acts. I couldn't compete with the majors, and made no attempt to do so. (Slagel 2017, p. 75)

Available sources of German labels give little reason to presume that they intended to develop their bands to be sold profitably to major labels. At least for the bigger companies Noise, Century Media and Nuclear Blast, interview statements indicate that increased revenues were spent on production, touring and promotion to support their bands. These labels also used income from successful artists to subsidise smaller bands to improve their chances of growing and becoming the next generation of successful artists, who would, in turn, support emerging newcomers.

The data suggests that German labels had a nuanced relationship with the major labels. For the three just mentioned labels, it is documented that they occasionally collaborated with major labels if it was beneficial to their top bands, not much different from the reasons Brian Slagel (2017) and Jon Zazula (2019) stated. At most times, however, they collaborated with each other. For example, Century Media shared operations with Noise and Nuclear Blast in the USA since the mid-1990s and licensed the catalogue of SPV and fellow German progressive metal label InsideOut (Krumm 2012), seeing good business relations as a 'code of honour' (Krumm 2012, p. 203). Similarly, Brian Sharp of Century Media USA described the labels' mutual wish for bands not to move to the majors but to their fellow German competitors: 'If a band leaves Century Media, we would rather have them with Nuclear Blast than with any other company' (Krumm 2012, p. 
102; translation). This intention to keep bands should not be equated with hindering prospective bands from growing and obtaining more support from a major company. While with Steamhammer, Noise, Century Media and Nuclear Blast all four leading German metal labels of the 1980s and 1990s were initially distributed by German independent SPV, they eventually created their own distribution channels in key international markets to allow genre-appropriate promotion and distribution, as well as more efficient and coherent operations (Wells 2017, pp. 185-186). These infrastructures were extended by distribution deals with major labels, combining the benefits for a band to be managed by an independent label with the distribution power of a major label (Negus 1999, p. 59; Wells 2017). Based on the metal magazine discourse, it was advantageous for a band's image to be signed to an independent rather than a major label (see also Negus 2001, p. 18). Bands with a major label like Axxis (EMI) were sometimes mocked in the press and disliked by metal fans. After their reunion and change to German independent labels Massacre and AFM, Axxis-perhaps to make peace with having lost their major company support-highlighted the advantages of a German indie label because they had less external pressure (Mineur 2004b), even though it forced them to open a recording studio and music publishing company to remain "professional" (Mineur 2004a).

\section{Conclusion}

Underground musical subcultures have a complex relationship with the culture industry, especially those rejecting commerce for ideological reasons, as is usual in metal. This study has focused on the beginnings of West German metal and its rock precursors to unfold the lesser reported positive sides of the recording industry. In contrast to the often-portrayed enemy image with instrumentalist, capitalist intentions, the early German rock and metal music industries were predominantly community-oriented and sustained by serious amateurs, semi-professionals and a few professionals. Many held to their principles in the community's interest, putting moral standpoints above economic viability under considerable personal investments and financial losses. As a result, not many of the companies survived. While a few remained, new ones have opened (e.g., Massacre, GUN, InsideOut, AFM), supporting the domestic metal scene and being home to many foreign bands that choose to work with German indie labels. After decades of lagging behind the Anglo-American recording industry, Germany has become one of the prime music production centres for metal music.

Literature has highlighted the importance of independent record labels for the emergence and development of underground music. Typically, such companies discover and promote promising artists to a point where the majors can pick them up. In the historically dominant metal countries, the UK and the USA, this pipeline mechanism helped internationally popular bands move quickly from independent labels like Metal Blade, Megaforce and Neat to major companies. Not so in Germany, where few bands like Helloween chose, only temporarily, a major. Most bands remained loyal to the many German independent labels of varying standing, 
depending on their level of success. Financial agreements and revenues are a wellkept secret, so journalistic sources do not give clues whether German (and foreign) bands preferred or had no choice but to work with German independent labels. As to how culturally formed mentalities may influence decision-making can only be speculated. German rock music of the 1970s was significantly shaped by a left-wing countercultural spirit, of which Rolf-Ulrich Kaiser and his business partners, above all producer Conny Plank and Dieter Dierks, are apt examples alongside the many idiosyncratic krautrock bands. This leftist mentality was still prevalent in the 1980s metal hotspots in Germany, especially in the industrial Ruhr Area, where most record labels, magazines and bands were located. While some direct links between krautrock and early German metal were found in this study, other connections were less tangible. It is nevertheless safe to assume that krautrock's heritage contributed to the emergence of a supportive German metal industry that persistently manages the balancing act between economic viability and its mission to maintain and grow the metal community.

Research in popular music has focused on the ethical superiority of independent record labels compared to the major corporations. This study did not aim to compare various kinds of record labels but nevertheless contributes to the discourse. The finding that independent labels support the metal scene by serving as cultural intermediaries, enabling serious amateurs and semi-professionals to create a functioning and now professional metal music industry and leisure space for creatives and metal fans alike, is further evidence that the "culture industry" does not necessarily have to be socially manipulative and purely motivated by financial gain. Music-related commerce and leisure are not mutually exclusive. Without commercial activity, there can be no significant leisure space. Instead of seeing these two only as competing forces, it would be more productive to explore how the relationship works for both. In other words: How can artists - supported by companies-produce and release music that is accessible to fans near and far with few creative constraints, and how can this process be economically sustainable enough for businesses to survive and fund artistic projects, some of which may be aesthetically valuable but not commercially profitable? What is clear is that many record labels are not the "enemy" they are often portrayed as — at least in a community-oriented music genre like metal.

Funding Not applicable.

Data Availability Not applicable.

\section{Declarations}

Conflict of interest The authors declare that they have no conflict of interest.

Ethical Approval Not applicable.

Open Access This article is licensed under a Creative Commons Attribution 4.0 International License, which permits use, sharing, adaptation, distribution and reproduction in any medium or format, as long as you give appropriate credit to the original author(s) and the source, provide a link to the Creative 
Commons licence, and indicate if changes were made. The images or other third party material in this article are included in the article's Creative Commons licence, unless indicated otherwise in a credit line to the material. If material is not included in the article's Creative Commons licence and your intended use is not permitted by statutory regulation or exceeds the permitted use, you will need to obtain permission directly from the copyright holder. To view a copy of this licence, visit http://creativecommons.org/ licenses/by/4.0/.

\section{References}

Adelt, U. (2016). Krautrock: German music in the seventies. University of Michigan Press.

Adorno, T. (1976). Introduction to the sociology of music. Seabury.

Adorno, T. (1991). The culture industry. Routledge.

Adorno, T., \& Horkheimer, M. (1979). Dialectic of enlightenment. Verso.

Ahlig, E., \& Zahn, T. (2013). 25 Jahre Nuclearer Wahnsinn. Metal Hammer, 2013(1), 60-63.

Altheide, D. L., \& Schneider, C. J. (2013). Qualitative media analysis. Sage.

Bacon, W. (1997). The rise of the German and the demise of the English spa industry: A critical analysis of business success and failure. Leisure Studies, 16, 173-187.

Benjamin, B. (1969). Illuminations. Shocken.

Bourdieu, P. (1986). Distinction. A social critique of the judgment of taste. Routledge.

Bowen, G. A. (2009). Document analysis as a qualitative method. Qualitative Research Journal, 9(2), $27-40$.

Buffo. (2002). Soilwork: Paukerschwemme in Helsingborg. Rock Hard, 2002(5), 38-40.

Corbin, J. M., \& Strauss, A. L. (2008). Basics of qualitative research. Techniques and procedures for developing grounded theory. Sage.

Denisoff, R. S. (1975). Solid gold: The popular record industry. Transaction Books.

Elflein, D. (2017). Restless and wild: Early West German heavy metal. In M. Ahlers \& C. Jacke (Eds.), Perspectives on German popular music (pp. 116-122). Routledge.

Engelking, P. (2007). Nuclear Blast: Vom Underground an die Spitze. Heavy Oder Wass, 2007/12, 36-37.

Finnegan, R. (1989). The hidden musician: Music-making in an English town. Cambridge University Press.

Gehlke, D. E. (2017). Damn the machine: The story of Noise Records. Deliberation Press.

Gillett, C. (2011). The sound of the city: The rise of rock \& roll. Souvenir Press.

Glaser, B. G., \& Strauss, A. L. (1976). Discovery of grounded theory. Strategies for qualitative research. Aldine de Gruyter.

Glaub, C. (1995). Die 3650 Tage von Sodom. Break out, 1995(1), 33.

Golding, P., \& Murdock, G. (1996). Culture, communications, and political economy. In J. Curran \& M. Gurevitch (Eds.), Mass media and society (pp. 11-30). Arnold.

Habermas, J. (1984). The theory of communicative action one: Reason and the rationalization of society. Polity.

Halmshaw, P. (2019). (Anything for a) Peaceville life. Cult Never Dies.

Halupczok, M. (2010). Von Goslar bis New York. Metal Hammer, 2010(4), 30-33.

Hennion, A. (1983). An intermediary between production and consumption: The producer of popular music. Science, Technology and Human Values, 14(4), 400-424.

Herbst, J.-P. (2019). The formation of the West German power metal scene and the question of a 'Teutonic' sound. Metal Music Studies, 5(2), 201-223.

Herbst, J.-P. (2020a). From Bach to Helloween: 'Teutonic' stereotypes in the history of popular music. Metal Music Studies, 6(1), 87-108.

Herbst, J.-P. (2020b). German metal attack: Power metal in and from Germany. In O. Seibt, M. Ringsmut, \& D.-E. Wickström (Eds.), Made in Germany (pp. 81-89). Routledge.

Herbst, J.-P. (2021a). Culture-specific production and performance characteristics: An interview study with 'Teutonic' metal producers. Metal Music Studies, 7(3), 1.

Herbst, J.-P. (2021b). Recording studios as museums? Record producers' perspectives on German rock studios and accounts of their heritage practice. Popular Music, 40(2), 91-113.

Herbst, J.-P. (2022). Infrastructure of the German music business. In U. Schütte (Ed.), The Cambridge companion to krautrock. Cambridge University Press. 
Herbst, J.-P., \& Bauerfeind, K. (2021). Teutonic metal: Effects of place- and mythology-based labels on record production. International Journal for the Sociology of Leisure. https://doi.org/10.1007/ s41978-021-00084-5

Hesmondhalgh, D. (1996). Flexibility, post-Fordism and the music industries. Media, Culture and Society, 18(3), 469-488.

Hesse, P. (2006). Karl-Ulrich Walterbach. Deaf Forever, 2006(13), 27-28.

Hilbig, G. (1985). Gama Musikverlag und Spygel Tonstudios. Metal Hammer, 1985(2), 68.

Himmelstein, A. (2001). Kreator: Revolutionen müssen laut sein. Rock Hard, 2001(10), 24-25.

Hjelm, T., Kahn-Harris, K., \& LeVine, M. (2011). Heavy metal as controversy and counterculture. Popular Music History, 6(1/2), 5-18.

Hull, G. P., Hutchison, T. W., \& Strasser, R. (2011). The music business and recording industry: Delivering music in the 21 st century. Routledge.

Jaedike, J. (2001). Destruction: Knüppel schlägt Strumpfhose. Rock Hard, 2001(10), 22-23.

Jaedike, J. (2004). Tankard: Total anal. Rock Hard, 2004(5), 94-95.

Kahn-Harris, K. (2007). Extreme metal. Berg.

Kerzel, S. (1989). Der Hardrock and Heavy Metal-Studio Report. Metal Hammer, 1989(10), 78-79.

Kleiner, F. (1986). Grave Digger: Vom Hexenjäger zum Kriegsberichterstatter. Metal Hammer, 1986(2), 43.

Klemm, O. (1985). Running Wild: Deutsche Newcomer der zweiten HM Generation auf dem Vormarsch. Metal Hammer, 1985(11), 40-41.

Klemm, O. (1987). Noise Records: Hintergrund und Politik eines HM-Labels. Metal Hammer, 2, 136-137.

Klüsener, E. (1988). Heavy Sounds vom Leinestrand: Das Horus Sound-Studio. Metal Hammer, $1988(10), 30-31$.

Klüsener, E. (1989). Ist Westdeutschland ein rockmusikalisches Entwicklungsland? Metal Hammer, 1989(3), 134-135.

Krumm, C. (2011). "Auf einmal ist es explodiert": Die Entstehung der Metalszene im Ruhrgebiet. In R. F. Nohr \& H. Schwaab (Eds.), Metal matters: Heavy metal als Kultur und Welt (pp. 357-366). LIT.

Krumm, C. (2012). Century Media - Do It Yourself: Die Geschichte eines Labels. Schmenk.

Kühnemund, G. (1988a). Rückblick 1987: Das HM-Jahr schlechthin? Metal Hammer, 1988(1), 16-17.

Kühnemund, G. (1988b). Sodom: Von allen guten Geistern verlassen? Rock Hard, 1988(3), 136.

Lee, S. (1995). Re-examining the concept of the 'independent' record company: The case of Wax Trax! Records. Popular Music, 14(1), 13-31.

Mader, M., Jeske, O., \& Hofmann, A. (1998). Heavy metal made in Germany. IP-Verlag.

Mall, A. (2018). Concentration, diversity, and consequences: Privileging independent over major record labels. Popular Music, 37(7), 444-465.

Messick, K. J. (2020). Metal for the masses: How indie metal labels have adapted for the digital era. Center for Open Science. https://doi.org/10.31219/osf.io/a758b

Miller, D. L. (2018). Sustainable and unsustainable semi-professionalism: Grassroots music careers in folk and metal. Popular Music \& Society, 41(1), 71-88.

Mineur, M. (2004a). Axxis: Die Zeiten werden härter. Metal Hammer, 2004(3), 58.

Mineur, M. (2004b). Axxis: Europa im Visier. Metal Hammer, 2004(1), 29.

Mineur, M. (2004c). Nuclear Blast. Metal Hammer, 2004(1), 52-53.

Mineur, M. (2007). 20 Jahre Nuclear Blast Records. Metal Hammer, 2007(11), 48-49.

Mühlmann, W.-R. (2008). Rock pop in concert 1983. Metal Hammer, 2008(9), 58-69.

Negus, K. (1999). Music genres and corporate cultures. Routledge.

Negus, K. (2001). Producing pop: Culture and conflict in the popular music industry. Arnold.

Negus, K. (2010). Popular music in theory: An introduction. Polity Press.

Netherton, J. (2017). The entrepreneurial imperative: Recording artists in extreme metal music protomarkets. Metal Music Studies, 3(3), 369-386.

Neudi. (2017). Aaarrg records. All killer, no filler! Deaf Forever, 20, 140-143.

Okunew, N. (2021). Red metal: Die Heavy-Metal-Subkultur der DDR. Christoph Links Verlag.

Parker, S. (1971). The future of work and leisure. MacGibbon and Kee.

Penzel, M. (1989). Szene D: Majors und Indies. Metal Hammer, 1989(4), 118-121.

Reetze, J. (2020). Times \& sounds: Germany's journey from Jazz and Pop to krautrock and beyond. Halvmall.

Rinne, C. (1984). Steamhammer. Metal Hammer, 1984(12), 67.

Rogan, J. (1988). Starmakers and Svengalis. Futura. 
Schmenk, H., \& Krumm, C. (2010). Kumpels in Kutten: Heavy Metal im Ruhrgebiet. Bottrop: Bücher vonne Ruhr.

Simmeth, A. (2016). Krautrock transnational: Die Neuerfindung der Popmusik in der BRD, 1968-1978. Bielefeld.

Slagel, B. (2017). For the sake of heaviness: The history of Metal Blade Records. BMG.

Spracklen, K. (2009). The meaning and purpose of leisure. Palgrave.

Spracklen, K. (2011). Constructing leisure: Historical and philosophical debates. Palgrave.

Spracklen, K. (2013). Nazi punks folk off: Leisure, nationalism, cultural identity and the consumption of metal and folk music. Leisure Studies, 32(4), 415-428.

Spracklen, K. (2014). There is (almost) no alternative: The slow 'heat death' of music subcultures and the instrumentalization of contemporary leisure. Annals of Leisure Research, 17(3), 252-266.

Spracklen, K. (2019). Opeth not metal: Making sense of the symbolic boundary work in the leisure spaces of musicians and fans. International Journal of the Sociology of Leisure, 2, 267-284.

Spracklen, K. (2020). Metal music and the re-imagining of masculinity, place, race and nation. Emerald Publishing.

Stebbins, R. A. (2009). Leisure and consumption: Common ground/separate worlds. Palgrave Macmillan.

Stebbins, R. A. (2017). Leisure music production: Its spaces and places. In R. Mantie \& G. D. Smith (Eds.), The Oxford handbook of music making and leisure (pp. 347-363). Oxford University Press.

Strachan, R. (2007). Micro-independent record labels in the UK. Discourse, DIY, cultural production and the music industry. European Journal of Cultural Studies, 10(2), 245-265.

Stratmann, H. (2004). Robert Kampf: Im Gespräch mit dem Century Media Gründer. Rock Hard, 2004(10), 50-52.

Stratmann, H. (2015). German Metal Spezial: Sauerkraut erobert die Welt. Rock Hard, 2015(11), 14-20.

Stubbs, D. (2014). Future days: Krautrock and the building of modern Germany. Faber \& Faber.

Tiamat. (1994). Wild honey. Century Media.

Tucker, J. (2015). Neat \& tidy: The story of Neat Records. Iron Pages.

Wade Morris, J. (2014). Artists as entrepreneurs, fans as workers. Popular Music \& Society, 37(3), 273-290.

Waksman, S. (2009). This ain't the summer of love: Conflict and crossover in heavy metal and punk. University of California Press.

Wallach, J., Berger, H. M., \& Greene, P. D. (Eds.). (2011). Metal rules the globe: Heavy metal around the world. Duke University Press.

Weckmann, M. (2017). 30 Jahre Mosh am Bügelbrett: Nuclear Blast. Metal Hammer, 2017(7), 38-39.

Weinstein, D. (2011). The globalization of metal. In J. Wallach, H. M. Berger, \& P. D. Greene (Eds.), Metal rules the globe: Heavy metal around the world (pp. 34-59). Duke University Press.

Wells, L. S. (2017). Independent record labels and record deals. In M. Halloran (Ed.), The musician's business and legal guide (pp. 182-198). Taylor and Francis.

Zaddach, W.-G. (2018). Heavy Metal in der DDR: Szene, Akteure, Praktiken. Bielefeld.

Zazula, J. (2019). Heavy tales: The metal. The music. The madness. CraZed Management.

Publisher's Note Springer Nature remains neutral with regard to jurisdictional claims in published maps and institutional affiliations. 